\title{
Involvement of Human Histamine N-Methyltransferase Gene Polymorphisms in Susceptibility to Atopic Dermatitis in Korean Children
}

\author{
Hee Seon Lee, ${ }^{1+}$ Seung-Hyun Kim, ${ }_{1}^{2+}$ Kyung Won Kim, ${ }_{1}^{1}$ Ji Young Baek, ${ }_{1}^{1}$ Hae-Sim Park, ${ }_{1}$ Kyung Eun Lee, ${ }_{1}^{1}$ \\ Jung Yeon Hong, ${ }^{1}$ Mi Na Kim, ${ }^{1}$ Won $I I$ Heo, ${ }^{1}$ Myung Hyun Sohn, ${ }^{1 *}$ Kyu-Earn Kim ${ }^{1}$
'Department of Pediatrics and Institute of Allergy, Severance Biomedical Science Institute, BK21 Project for Medical Science, Yonsei University College of Medicine, Seoul, Korea
${ }^{2}$ Department of Allergy and Rheumatology, Ajou University School of Medicine, Suwon, Korea

\begin{abstract}
This is an Open Access article distributed under the terms of the Creative Commons Attribution Non-Commercial License (http://creativecommons.org/licenses/by-nc/3.0/) which permits unrestricted non-commercial use, distribution, and reproduction in any medium, provided the original work is properly cited.
\end{abstract}

\begin{abstract}
Purpose: Histamine N-methyltransferase (HNMT) catalyzes one of two major histamine metabolic pathways. Histamine is a mediator of pruritus in atopic dermatitis (AD). The aim of this study was to evaluate the association between HNMT polymorphisms and AD in children. Methods: We genotyped 763 Korean children for allelic determinants at four polymorphic sites in the HNMT gene: $-465 T>C,-413 C>T, 314 C>T$, and 939A $>G$. Genotyping was performed using a TaqMan fluorogenic 5 ' nuclease assay. The functional effect of the 939A $>G$ polymorphism was analyzed. Results: Of the 763 children, 520 had eczema and 542 had atopy. Distributions of the genotype and allele frequencies of the HNMT314C>T polymorphism were significantly associated with non-atopic eczema $(P=0.004)$, and those of $H N M T 939 \mathrm{~A}>\mathrm{G}$ were significantly associated with eczema in the atopy groups $(P=0.048)$. Frequency distributions of $H N M T-465 T>C$ and $-413 C>T$ were not associated with eczema. Subjects who were AA homozygous or $A G$ heterozygous for $939 A>G$ showed significantly higher immunoglobulin $E$ levels than subjects who were $G G$ homozygous $(P=0.009)$. In U937 cells, the variant genotype reporter construct had significantly higher mRNA stability $(P<0.001)$ and HNMT enzyme activity $(P<0.001)$ than the common genotype. Conclusions: Polymorphisms in HNMT appear to confer susceptibility to AD in Korean children.
\end{abstract}

Key Words: Atopic dermatitis; children; histamine, N-Methyltransferase; polymorphism

\section{INTRODUCTION}

Atopic dermatitis (AD) is a chronic pruritic inflammatory skin disease caused by complex interactions among various susceptibility genes, host environment, infectious agents, skin barrier defects, and immunological responses. ${ }^{1}$ The prevalence of $\mathrm{AD}$ has doubled or tripled in industrialized countries during the past three decades. ${ }^{2}$ In Korea, an increased prevalence of symptoms, diagnosis, and treatment of $\mathrm{AD}$ has been noted. ${ }^{3} \mathrm{AD}$ often represents the first clinical manifestation of atopy in childhood and suggests a high risk for the development of asthma. ${ }^{4}$ The underlying pathology of $\mathrm{AD}$ is complex, with interactions among genes and environmental factors contributing to disease manifestation. ${ }^{5}$

Histamine is released from mast cells and basophils, and is an important mediator in the development of allergic diseases. Histamine is degraded by two major metabolic pathways involving the enzymes histamine N-methyltransferase (HNMT) and diamine oxidase (DAO; ABP1), respectively. ${ }^{6}$ DAO may scavenge extracellular histamine, whereas HNMT catalyzes the inactivation of intracellular histamine. The HNMT gene, located on the long arm of chromosome 2 (q22.1), is approximately $34 \mathrm{~kb}$ in length, with six exons and a second intron of approximately $15 \mathrm{~kb} .^{7}$

Of the eight reported polymorphisms in HNMT, only three are common single nucleotide polymorphisms (SNPs): $-463 \mathrm{~T}>\mathrm{C}$, $314 \mathrm{C}>\mathrm{T}$, and $939 \mathrm{~A}>\mathrm{G} .{ }^{8}$ For $314 \mathrm{C}>\mathrm{T}$, a nonsynonymous poly-

Correspondence to: Myung Hyun Sohn, MD, PhD, Department of Pediatrics and Institute of Allergy, Severance Biomedical Science Institute, Brain Korea 21 Project for Medical Science, Yonsei University College of Medicine,

50 Yonsei-ro, Seodaemun-gu, Seoul 120-752, Korea.

Tel: +82-2-2228-2050; Fax: +82-2-393-9118; E-mail: mhsohn@yuhs.ac

${ }^{\dagger}$ The first two authors contributed equally to this work.

Received: July 11, 2011; Accepted: September 15, 2011

- There are no financial or other issues that might lead to conflict of interest. 
morphism which results in a change from threonine to isoleucine at amino acid 105, the $314 \mathrm{~T}$ allele is associated with decreased enzyme activity of HNMT. ${ }^{8}$ In a study of Chinese females, $-1,637 \mathrm{~T}>\mathrm{C}$ or $-463 \mathrm{~T}>\mathrm{C}$ tended to be associated with decreased HNMT activity, and 939A $>$ G or 1097A $>$ T was associated with increased enzyme activity. ${ }^{9}$ In another study, the variant HNMT allele frequencies were slightly higher in patients with asthma and rhinitis as compared with healthy subjects. ${ }^{10}$ In our previous study, ${ }^{11}$ the $939 \mathrm{~A}>\mathrm{G}$ polymorphism was significantly associated with the acetylsalicylic acid-intolerant chronic urticaria phenotype in adult patients, and the variant genotype of the $939 \mathrm{~A}>\mathrm{G}$ polymorphism showed higher mRNA stability and increased enzyme activity. However, to our knowledge, there is only one study of HNMT polymorphisms in $\mathrm{AD}$ patients, which demonstrated a significant association between $\mathrm{AD}$ and $314 \mathrm{C}>\mathrm{T}$ in $H N M T .^{12}$

The purpose of this study was to evaluate the role of HNMT gene in susceptibility to $\mathrm{AD}$ by investigating the polymorphisms of this gene in Korean children with $\mathrm{AD}$

\section{MATERIALS AND METHODS}

\section{Subjects}

A total of 763 children were recruited from Severance Children's Hospital of Yonsei University for this study. These subjects included 396 children with atopic eczema, 124 children with non-atopic eczema, 146 atopic controls, and 97 non-atopic controls.

All patients with $\mathrm{AD}$ were diagnosed according to the criteria of Hanifin and Rajka. ${ }^{13}$ We excluded children with $\mathrm{AD}$ who also had respiratory allergies. In this study, we divided patients with AD patients into atopic eczema and non-atopic eczema. ${ }^{14}$ Tests for specific immunoglobulin E (IgE) against Dermatophagoides pteronyssinus, Dermatophagoides farinae, egg whites, cow's milk, peanuts, and soybeans were performed, as these represent six common allergens in Korea. Children with atopy were sensitive to one or more of the six common allergens, and their total IgE level was $>150 \mathrm{IU} / \mathrm{mL}$. The total serum IgE level of children without atopy was $<150 \mathrm{IU} / \mathrm{mL}$, with no detectable specific IgE antibodies to any of the six common allergens. Controls were children who visited the hospital for general health checkups and did not have any history of allergic or inflammatory disease. Written informed consent was obtained from all participants before enrollment in the study, which was approved by the Severance Hospital Institutional Review Board.

\section{Measurement of blood eosinophils and serum total and specific lgE levels}

Peripheral blood samples were obtained from the subjects, and the levels of total IgE and specific IgE against each of the six common antigens were measured using a fluorenzymeimmunoassay (CAP FEIA; Pharmacia \& Upjohn Diagnostic AB, Up- psala, Sweden) according to the manufacturer's instructions. Specific IgE levels $>0.35 \mathrm{kUA} / \mathrm{L}$ were considered positive. A hematology analyzer (NE-8000; Sysmax, Kobe, Japan) was used to automatically count peripheral blood eosinophils.

\section{Genotyping and PCR amplification}

Whole blood was obtained from each subject, and genomic DNA was extracted using a FlexiGene DNA kit (Qiagen, Valencia, CA, USA). We genotyped the allelic determinants of the 763 children at four known polymorphic sites in the HNMT gene: $-465 \mathrm{~T}>\mathrm{C},-413 \mathrm{C}>\mathrm{T}, 314 \mathrm{C}>\mathrm{T}$, and $939 \mathrm{~A}>\mathrm{G} .{ }^{8,9,15}$ Genotyping was performed using a TaqMan fluorogenic 5 ' nuclease assay (ABI, Foster City, CA, USA). The polymerase chain reaction (PCR) contained 10 ng of genomic DNA, $2.5 \mu \mathrm{L}$ of TaqMan Universal PCR Master Mix, and $0.13 \mu \mathrm{L}$ of $40 \times$ assay mix in a final volume of $5 \mu \mathrm{L}$. Thermal cycle conditions were: $50^{\circ} \mathrm{C}$ for 2 minutes to activate uracil N-glycosylase and prevent carry-over contamination, and $95^{\circ} \mathrm{C}$ for 10 minutes to activate DNA polymerase, followed by 45 cycles of $95^{\circ} \mathrm{C}$ for 15 seconds and $60^{\circ} \mathrm{C}$ for $1 \mathrm{~min}$ ute. All PCRs were performed in 384-well plates with a Dual 384-Well GeneAmp PCR System 9700 (ABI). Endpoint fluorescence readings were performed using a Prism 7900 HT sequence detection system (ABI). Duplicate samples and negative controls were included to ensure the accuracy of genotyping.

\section{mRNA stability according to the $939 \mathrm{~A}>\mathrm{G}$ polymorphism}

Two luciferase reporter constructs for the common and variant genotypes of 939A > G, which comprised a 535-bp fragment (from nt 880 to 1,415 ), were transiently transfected into a myelomonocytic cell line (U937) by electroporation. Briefly, $1 \times 10^{6}$ cells were seeded in six-well plates, transfected with $2 \mu \mathrm{g}$ of an enhanced green fluorescent protein (EGFP) reporter plasmid (pEGFP-HNMT 3'-UTR), and incubated for 18 hours. Then, actinomycin D ( $10 \mu \mathrm{g} / \mathrm{mL}$; Sigma, St. Louis, MO, USA) was added, and the cells were collected at $0,0.5,1,2,4$, and 6 hours.

EGFP mRNA levels were assessed by real-time PCR using a thermocycler and Prism 7500HT sequence detection system $(\mathrm{ABI})^{11}$. The EGFP mRNA expression level was normalized to that of $\beta$-actin.

EGFP protein levels were assessed by measuring fluorescence intensity with a Synergy HT multi-detection microplate reader (BioTek Instruments, Winooski, VT, USA). Fluorescence intensities are given in relative fluorescence units calculated relative to the values of mock-treated cells. Autofluorescence of nontransfected cells was measured as a negative control. EGFP protein expression levels were normalized to total protein concentration.

HNMT enzyme activity according to the $939 \mathrm{~A}>\mathrm{G}$ polymorphism

Transfection of pHNMT CDS-3'-UTR constructs into U937 cells and the measurement of HNMT activity in cell lysates were performed as previously described. ${ }^{11}$ Radioactivity was measured 
using a liquid scintillation counter (LS-3801; Beckman Instruments, Irvine, CA, USA). Enzyme activity was measured as the formation of $\mathrm{N} \tau$-methylhistamine per hour of incubation at $37^{\circ} \mathrm{C}$.

\section{Statistical analysis}

Statistical analyses were performed using SPSS ver. 11.5 (SPSS Inc., Chicago, IL, USA). The Chi-squared test was used to detect a significant departure from Hardy-Weinberg equilibrium for the genotype frequency of each SNP and to assess differences in genotype frequencies between patients and controls. SNPs were analyzed by logistic regression with three alternative models (co-dominant, dominant, and recessive), controlling for age and gender as covariates. Fisher's exact test was used when expected cell frequencies were less than five. Differences in mean phenotypic values were compared using Student's $t$-test. Significance was indicated by $P<0.05$. Bonferroni's correction was used for multiple comparisons.

\section{RESULTS}

\section{Characteristics of subjects}

The characteristics of the study subjects are summarized in Table 1. There were significant differences in age and gender among the four groups $(P<0.05)$. Total IgE levels were significantly higher in the atopic eczema group than in the other groups, and were higher in the atopic control group than in the non-atopic eczema group or non-atopic controls $(P<0.05)$. Blood eosinophils were higher in the order of: atopic eczema, non-atopic eczema, atopic control, and non-atopic control groups $(P<0.05)$.

\section{Genotype and allele frequencies of HNMT polymorphisms}

We performed a genetic association study of four genetic polymorphisms of $H N M T$, $-465 \mathrm{~T}>\mathrm{C},-413 \mathrm{C}>\mathrm{T}, 314 \mathrm{C}>\mathrm{T}$, and $939 \mathrm{~A}>\mathrm{G}$, among the four subject groups. The genomic structure and linkage disequilibrium of HNMT are shown in Fig. 1.

The genotype distributions of the polymorphisms in the eczema and control groups of children without atopy are showed in Table 2. The heterozygous CT frequency of 314C $>$ T was significantly higher in the non-atopic eczema group than in the non-

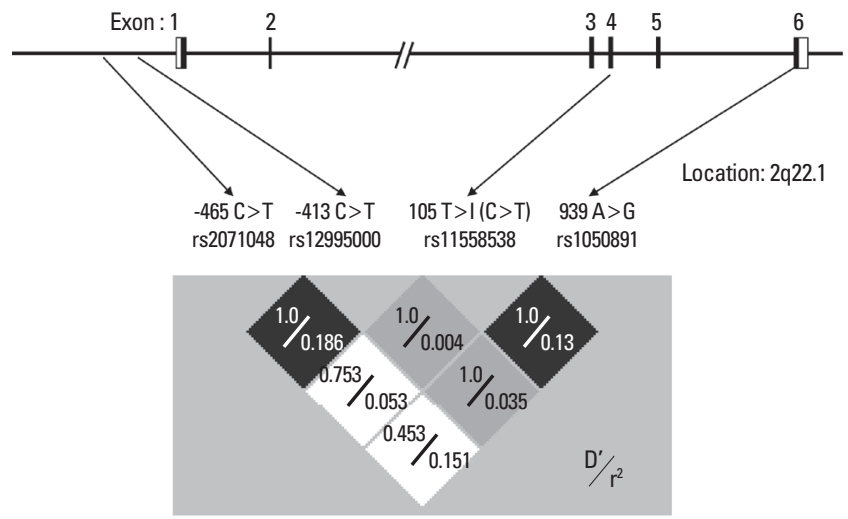

Fig. 1. Linkage-disequilibrium structure of histamine N-methyltransferase (HNMT) in Koreans. The upper diagram shows the genomic structure of HNMT. The lower diagram shows the linkage disequilibrium $\left(D^{\prime} / r^{2}\right)$ among the SNPs in this study.

Table 2. Genotype and allele frequencies of histamine N-methyltransferase (HNMT) polymorphisms in children without atopy

\begin{tabular}{lcccc}
\hline Locus & Genotype & $\begin{array}{c}\text { Non-atopic } \\
\text { eczema } \\
N=124, N(\%)\end{array}$ & $\begin{array}{c}\text { Non-atopic } \\
\text { non-eczema } \\
N=97, N(\%)\end{array}$ & $\begin{array}{c}P \text {-value } \\
\text { OR (95\% CI) }\end{array}$ \\
\hline$-465 T>C$ & $\Pi$ & $48(38.7)$ & $39(41.1)$ & 0.342 \\
& TC & $58(46.8)$ & $43(45.3)$ & \\
& CC & $18(14.5)$ & $13(13.7)$ & \\
$-413 C>T$ & CC & $105(84.7)$ & $77(79.4)$ & 0.018 \\
& CT & $18(14.5)$ & $19(19.6)$ & \\
& $\Pi 1$ & $1(0.8)$ & $1(1)$ & \\
$314 C>T$ & CC & $107(86.3)$ & $94(96.9)$ & 0.004 \\
& CT & $17(13.7)$ & $3(3.1)$ & 4.975 \\
& $\Pi$ & $0(0)$ & $0(0)$ & $(1.414-17.543)$ \\
939A $>$ G & AA & $59(47.6)$ & $50(52.6)$ & 0.229 \\
& AG & $55(44.4)$ & $41(43.2)$ & \\
& GG & $10(8.1)$ & $4(4.2)$ & \\
\hline
\end{tabular}

$P$ values were calculated using dominant models. Values in bold indicate statistical significance. For multiple comparisons of genotype and allele frequencies, Bonferroni's multiple adjustment was applied to the level of significance, which was set at $P<0.0125$ (0.05/4). Logistic regression analysis was applied to control for age and gender as covariables.

$N$, number of patients.

Table 1. Characteristics of study subjects

\begin{tabular}{lccccc}
\hline Characteristic & $\begin{array}{c}\text { Atopic eczema } \\
(N=396)\end{array}$ & $\begin{array}{c}\text { Non-atopic eczema } \\
(N=124)\end{array}$ & $\begin{array}{c}\text { Atopic non-eczema } \\
(N=146)\end{array}$ & $\begin{array}{c}\text { Non-atopic non-eczema } \\
(N=97)\end{array}$ & $P$-value \\
\hline Age, years $($ mean $\pm S D)$ & $6.58 \pm 3.91$ & $4.35 \pm 3.04$ & $10.45 \pm 2.75$ & $9.18 \pm 3.01$ & $<0.001$ \\
Male gender, $N(\%)$ & $225(56.8)$ & $59(47.6)$ & $91(62.3)$ & $50(51.5)$ & 0.019 \\
$\lg$ (log IU/mL) & $5.88 \pm 1.44$ & $3.51 \pm 1.03$ & $4.94 \pm 1.81$ & $3.28 \pm 1.05$ & $<0.001$ \\
Eosinophil count $\left(\log \mu \mathrm{L}^{-1}\right)$ & $6.13 \pm 0.85$ & $5.75 \pm 0.77$ & $5.41 \pm 0.91$ & $4.75 \pm 0.84$ & $<0.001$ \\
\hline
\end{tabular}

Values in bold indicate statistical significance. $N$, number of patients; lgE, immunoglobulin $\mathrm{E}$. 
Table 3. Genotype and allele frequencies of histamine N-methyltransferase (HNMT) polymorphisms in children with atopy

\begin{tabular}{lcccc}
\hline Locus & Genotype & $\begin{array}{c}\text { Atopic eczema } \\
N=396, N(\%)\end{array}$ & $\begin{array}{c}\text { Atopic } \\
\text { non-eczema } \\
N=146, N(\%)\end{array}$ & $\begin{array}{c}P \text {-value } \\
\text { OR (95\% Cl) }\end{array}$ \\
\hline -465T>C & $\Pi$ & $182(46.5)$ & $182(46.5)$ & 0.896 \\
& TC & $167(42.7)$ & $167(42.7)$ & \\
& CC & $42(10.7)$ & $42(10.7)$ & \\
$-413 C>$ T & CC & $331(83.8)$ & $331(83.8)$ & 0.322 \\
& CT & $63(15.9)$ & $63(15.9)$ & \\
& $\Pi$ & $1(0.3)$ & $1(0.3)$ & \\
$314 C>T$ & CC & $359(90.7)$ & $359(90.7)$ & 1.000 \\
& CT & $37(9.3)$ & $37(9.3)$ & \\
& $\Pi$ & $0(0)$ & $0(0)$ & \\
939A $>$ G & AA & $208(52.9)$ & $208(52.9)$ & 0.048 \\
& AG & $167(42.5)$ & $167(42.5)$ & 0.415 \\
& GG & $18(4.6)$ & $18(4.6)$ & $(0.203-0.848)$ \\
\hline
\end{tabular}

$P$ values were calculated using dominant models. Values in bold indicate statistical significance. For multiple comparisons of genotype and allele frequencies, Bonferroni's multiple adjustment was applied to the level of significance, which was set at $P<0.0125$ (0.05/4). Logistic regression analysis was applied to control for age and gender as covariables.

$N$, number of patients.

atopic control group $(P=0.004)$. The genotype and allele frequencies of the $-465 \mathrm{~T}>\mathrm{C},-413 \mathrm{C}>\mathrm{T}$ and $939 \mathrm{~A}>\mathrm{G}$ polymorphisms did not differ significantly between these two groups.

Table 3 shows the genotype distributions of the polymorphisms in the eczema and control groups of children with atopy. The homozygous GG frequency of $939 \mathrm{~A}>\mathrm{G}$ was lower than the combined homozygous AA and heterozygous AG frequencies in the eczema group $(P=0.048)$. There were no significant differences in the genotype and allele frequencies of $-465 \mathrm{~T}>\mathrm{C}$, $-413 \mathrm{C}>\mathrm{T}$, and $314 \mathrm{C}>\mathrm{T}$ between these two groups.

\section{$\lg \mathrm{E}$ level classified by genotype distribution of the HNMT $939 \mathrm{~A}>\mathrm{G}$ polymorphism}

Total IgE was examined according to the genotype distribution of the HNMT 939A >G polymorphism. In children with atopy (Fig. 2A), the homozygous GG genotype of $939 \mathrm{~A}>\mathrm{G}$ was associated with significantly lower serum total IgE, compared with the combined homozygous AA and heterozygous AG genotypes $(P=0.009)$. In children with eczema, a significantly lower total IgE level was also associated with the $G$ allele. Patients who were homozygous GG for the $939 \mathrm{~A}>\mathrm{G}$ polymorphism tended to have significantly lower serum total $\operatorname{IgE}(P=0.011$; Fig. $2 \mathrm{~B})$, and genotypes AG and GG were associated with lower serum total IgE levels compared with the AA genotype $(P=0.007$; data not shown).

\section{Effect of the HNMT 939A $>\mathrm{G}$ polymorphism on mRNA stability}

We examined the association of the $939 \mathrm{~A}>\mathrm{G}$ polymorphism
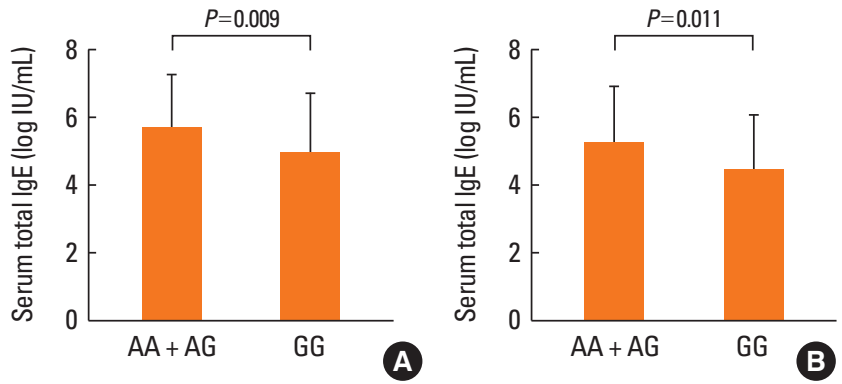

Fig. 2. Immunoglobulin E (lgE) level in children with atopy classified by distribution of the histamine $\mathrm{N}$-methyltransferase (HNMT) 939A $>\mathrm{G}$ polymorphism in $(A)$ children with atopy and $(B)$ children with eczema. After Bonferroni's correction for multiple comparisons, $P<0.0166(0.05 / 3)$ was considered to be statistically significant. Logistic regression analysis was applied to control for age and gender as covariables.
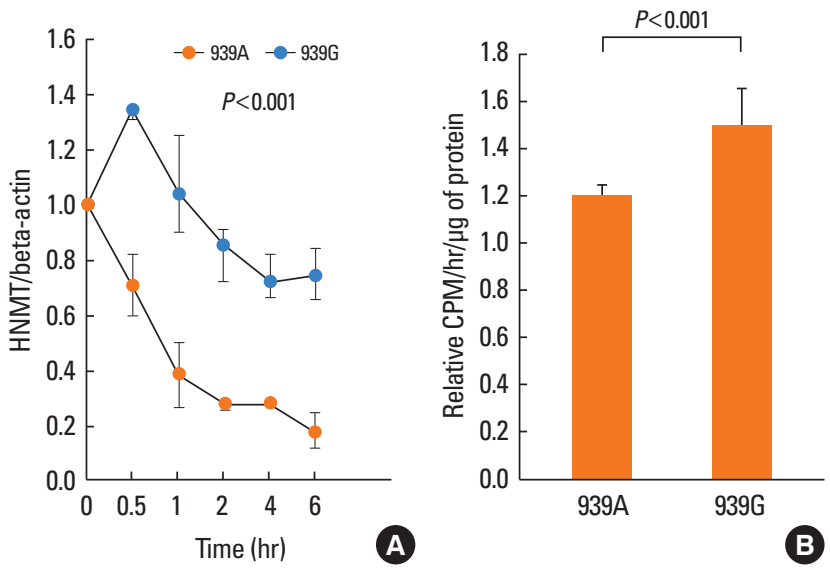

Fig. 3. Effect of the histamine N-methyltransferase (HNMT) 939A > G polymorphism on mRNA stability and enzyme activity. The mRNA levels of the pEGFPHNMT 3'-UTR reporter construct in U937 cells were assessed by real-time PCR after actinomycin $D(10 \mu \mathrm{g} / \mathrm{mL})$ treatment. (A) EGFP mRNA stability according to the $939 \mathrm{~A}>\mathrm{G}$ polymorphism. The $P$ value was determined using repeated measures ANOVA. (B) HNMT enzyme activity was examined by measuring the formation of N $\tau$-methylhistamine in pHNMT CDS-3'-UTR-transfected U937 cells. The relative enzyme activity (CPM: counts per minute) is represented as the ratio of the activity to the enzyme activity in cells transfected with the empty control vector pcDNA3. The $P$ value was determined by a Mann-Whitney test. Three independent determinations were performed on each sample.

with HNMT mRNA stability to identify the effect of the polymorphism on HNMT enzymatic activity. The mRNA stabilities of the $939 \mathrm{~A}$ and $939 \mathrm{G}$ alleles were analyzed by real-time PCR in U937 cells transfected with each genotype (939A or 939G) in the pEGFP-HNMT 3'-UTR construct, after actinomycin D (10 $\mu \mathrm{g} / \mathrm{mL}$ ) treatment. The mRNA of the 939G-fused reporter gene was significantly more stable than that of the 939A-fused reporter gene $(P<0.001)$. As seen in Fig. $3 \mathrm{~A}$, after actinomycin $\mathrm{D}$ treatment, the mRNA level of the 939A-fused reporter gene rapidly decreased, whereas that of the 939G-fused reporter gene decreased only slightly. We also investigated EGFP protein expression according to the $939 \mathrm{~A}>\mathrm{G}$ polymorphism by measuring the fluorescence signal from transfected U937 cells. The flu- 
orescence intensity induced by the $939 \mathrm{G}$-fused reporter gene was significantly higher than that induced by the 939A-fused reporter gene $(P=0.001$; data not shown $)$.

\section{In vitro functional study of the $H N M T$ 939A $>\mathrm{G}$ polymorphism}

We examined the effect of the $939 \mathrm{~A}>\mathrm{G}$ polymorphism on HNMT enzyme activity and histamine release. Enzyme activity was assayed by measuring the formation of $\mathrm{N} \tau$-methylhistamine in pHNMT CDS-3'-UTR-transfected U937 cells. Cells transfected with the HNMT 939G construct showed significantly higher enzyme activity than cells transfected with the HNMT 939A construct $(P<0.001$; Fig. 3B).

\section{DISCUSSION}

In this study, the effects of the HNMT $-465 \mathrm{~T}>\mathrm{C},-413 \mathrm{C}>\mathrm{T}$, $314 \mathrm{C}>\mathrm{T}$, and $939 \mathrm{~A}>\mathrm{G}$ polymorphisms on $\mathrm{AD}$ susceptibility in Korean children were investigated. The genotype and allele frequencies of $314 \mathrm{C}>\mathrm{T}$ in HNMT were significantly associated with non-atopic eczema, and the genotype and allele frequencies of 939A $>\mathrm{G}$ were associated with atopic eczema. Subjects with the GG genotype for 939A $>\mathrm{G}$ had significantly lower IgE levels than homozygous AA or heterozygous AG subjects. In a functional analysis, the variant genotype reporter construct in U937 cells showed significantly higher mRNA stability and HNMT enzyme activity than the common genotype.

The 314C $>$ T polymorphism, previously identified as a common nonsynonymous coding SNP located in HNMT exon 4, results in a Thr105Ile amino acid change. ${ }^{15}$ The function of the $314 \mathrm{~T}$ allele has been determined. ${ }^{6,8,15,16}$ Genotype-phenotype correlation analyses in HNMT pharmacogenetic studies ${ }^{8,15}$ have revealed a significant association of the $314 \mathrm{~T}$ allele with reduced thermal stability and decreased activity of HNMT. Based on these results, a role for the $314 \mathrm{C}>\mathrm{T}$ polymorphism in the pathogenesis of asthma and allergic diseases has been investigated. The 314C > T HNMT polymorphism was significantly associated with the asthma phenotype in Caucasian patients, ${ }^{16}$ but no significant association of this polymorphism with asthma, bronchial hyperresponsiveness, or other asthma-related phenotypes was detected in German children. ${ }^{17}$ Further studies also failed to identify an association of this polymorphism with asthma. ${ }^{10,18}$ In our previous study of adult patients with chronic urticaria, there was no significant association with the $314 \mathrm{C}>\mathrm{T}$ HNMT polymorphism. ${ }^{11}$ The only study of this polymorphism in $\mathrm{AD}$ patients suggested that the $314 \mathrm{C}>\mathrm{T}$ polymorphism may confer an increased risk for $\mathrm{AD}^{12}$ In the present study, the $314 \mathrm{C}>\mathrm{T}$ polymorphism was significantly associated with non-atopic eczema. The importance of histamine as a pruritic mediator in eczema $^{19}$ may explain the association between the $314 \mathrm{C}>\mathrm{T}$ polymorphism and non-atopic eczema.

The $939 \mathrm{~A}>\mathrm{G}$ polymorphism is a common SNP in $H N M T{ }^{15} \mathrm{~A}$ study in a European population reported no association be- tween 939A $>\mathrm{G}$ and food allergy, ${ }^{20}$ and a study in an Indian population found no association of this polymorphism with asthma. ${ }^{18}$ In our previous study, a significant association was demonstrated between the $939 \mathrm{~A}>\mathrm{G}$ polymorphism and the acetylsalicylic acid-intolerant chronic urticaria phenotype. ${ }^{11}$ In the present study, 939A $>\mathrm{G}$ was associated with atopic eczema. The GG genotype frequency of $939 \mathrm{~A}>\mathrm{G}$ was lower in the atopic eczema group compared with the atopic control group.

Interactions of IgE with its receptors are central to the phenomenon of allergy, and an elevated serum IgE level is an important diagnostic feature of $\mathrm{AD}{ }^{21}$ To our knowledge, no published study has suggested an association between 939A $>\mathrm{G}$ in $H N M T$ and the serum IgE level. Here, we detected a significant association between the $939 \mathrm{~A}>\mathrm{G}$ genotype distribution and serum IgE levels. In children with atopy and in those with eczema regardless of atopy, the homozygous GG genotype was significantly associated with lower serum IgE levels, compared with the other $939 \mathrm{~A}>\mathrm{G}$ genotypes. These results suggest a significant relationship between the $939 \mathrm{G}$ allele and lower IgE levels.

Although the $939 \mathrm{~A}>\mathrm{G}$ polymorphism in the $3^{\prime}$-UTR of HNMT has not been significantly correlated with HNMT phenotype, a study of a healthy Chinese population demonstrated that HNMT activity is modulated by the HNMT 939A $>$ G polymorphism. ${ }^{9,15}$ In the present study, the $939 \mathrm{G}$ genotype was significantly related to higher mRNA stability, increased protein expression, and higher enzyme activity. This replicated a previous study, which demonstrated an association between the $939 \mathrm{~A}>\mathrm{G}$ polymorphism and HNMT enzyme activity in chronic urticaria patients. ${ }^{11}$

Histamine plays a key role in human allergic reactions. The increased local and systemic histamine levels consistently detected in $\mathrm{AD}$ patients suggest an important role for histamine in the pathogenesis of $\mathrm{AD} .^{22} \mathrm{HNMT}$ catalyzes one of two major histamine metabolic pathways and is involved in the inactivation of intracellular histamine. ${ }^{6}$ Our data suggest that the $939 \mathrm{G}$ allele of the $939 \mathrm{~A}>\mathrm{G}$ polymorphism plays a protective role in $\mathrm{AD}$ by increasing HNMT enzyme activity, leading to reduced histamine levels. This is consistent with the action of histamine as a chemical mediator in the inflammation that contributes to AD disease pathogenesis. However, the association between the 939A $>\mathrm{G}$ polymorphism and $\mathrm{AD}$ phenotype became statistically insignificant after multiple correction. This may be partly explained by the contributions of additional inflammatory mediators to $\mathrm{AD}$ pathogenesis. Recent studies have demonstrated that activated mast cells can induce Th2 differentiation by modulating the function of maturing dendritic cells, and histamine functions in inducing Th2-promoting dendritic cells. ${ }^{23,24} \mathrm{IgE}$ is an end product of the $\mathrm{Th} 2$ response, and thus histamine may influence $\operatorname{IgE}$ production through $\mathrm{Th} 2$ differentiation..$^{23}$ The significant association of the 939G allele with lower IgE levels suggests that HNMT-mediated inactivation of histamine may affect serum IgE levels.

In conclusion, polymorphisms of the HNMT gene appear to 
confer susceptibility to AD in Korean children.

\section{ACKNOWLEDGMENTS}

This research was supported by the Basic Science Research Program through the National Research Foundation of Korea (NRF) funded by the Ministry of Education, Science, and Technology (2009-0075056).

\section{REFERENCES}

1. Akdis CA, Akdis M, Bieber T, Bindslev-Jensen C, Boguniewicz M, Eigenmann P, Hamid Q, Kapp A, Leung DY, Lipozencic J, Luger TA, Muraro A, Novak N, Platts-Mills TA, Rosenwasser L, Scheynius A, Simons FE, Spergel J, Turjanmaa K, Wahn U, Weidinger S, Werfel T, Zuberbier T. Diagnosis and treatment of atopic dermatitis in children and adults: European Academy of Allergology and Clinical Immunology/American Academy of Allergy, Asthma and Immunology/PRACTALL Consensus Report. J Allergy Clin Immunol 2006; 118:152-69.

2. Williams H, Flohr C. How epidemiology has challenged 3 prevailing concepts about atopic dermatitis. J Allergy Clin Immunol 2006; 118:209-13.

3. Hong SJ, Ahn KM, Lee SY, Kim KE. The prevalences of asthma and allergic diseases in Korean children. Korean J Pediatr 2008;51:34350.

4. Holloway JW, Yang IA, Holgate ST. Genetics of allergic disease. J Allergy Clin Immunol 2010;125:S81-94.

5. Barnes KC. An update on the genetics of atopic dermatitis: scratching the surface in 2009. J Allergy Clin Immunol 2010;125:16-29.e111.

6. García-Martín E, Ayuso P, Martínez C, Blanca M, Agúndez JA. Histamine pharmacogenomics. Pharmacogenomics 2009;10:867-83.

7. Aksoy S, Raftogianis R, Weinshilboum R. Human histamine N-methyltransferase gene: structural characterization and chromosomal location. Biochem Biophys Res Commun 1996;219:548-54.

8. Wang L, Thomae B, Eckloff B, Wieben E, Weinshilboum R. Human histamine N-methyltransferase pharmacogenetics: gene resequencing, promoter characterization, and functional studies of a common 5'-flanking region single nucleotide polymorphism (SNP). Biochem Pharmacol 2002;64:699-710.

9. Chen GL, Wang H, Wang W, Xu ZH, Zhou G, He F, Zhou HH. Histamine N-methyltransferase gene polymorphisms in Chinese and their relationship with enzyme activity in erythrocytes. Pharmacogenetics 2003;13:389-97.

10. García-Martín E, García-Menaya J, Sánchez B, Martínez C, Rosendo R, Agúndez JA. Polymorphisms of histamine-metabolizing enzymes and clinical manifestations of asthma and allergic rhinitis. Clin Exp Allergy 2007;37:1175-82.
11. Kim SH, Kang YM, Cho BY, Ye YM, Hur GY, Park HS. Histamine Nmethyltransferase $939 \mathrm{~A}>\mathrm{G}$ polymorphism affects mRNA stability in patients with acetylsalicylic acid-intolerant chronic urticaria. Allergy 2009;64:213-21.

12. Kennedy MJ, Loehle JA, Griffin AR, Doll MA, Kearns GL, Sullivan JE, Hein DW. Association of the histamine N-methyltransferase C314T (Thr105Ile) polymorphism with atopic dermatitis in Caucasian children. Pharmacotherapy 2008;28:1495-501.

13. Hanifin JM. Diagnostic criteria for atopic dermatitis: consider the context. Arch Dermatol 1999;135:1551.

14. Johansson SG, Bieber T, Dahl R, Friedmann PS, Lanier BQ, Lockey RF, Motala C, Ortega Martell JA, Platts-Mills TA, Ring J, Thien F, Van Cauwenberge P, Williams HC. Revised nomenclature for allergy for global use: Report of the Nomenclature Review Committee of the World Allergy Organization, October 2003. J Allergy Clin Immunol 2004;113:832-6.

15. Preuss CV, Wood TC, Szumlanski CL, Raftogianis RB, Otterness DM, Girard B, Scott MC, Weinshilboum RM. Human histamine Nmethyltransferase pharmacogenetics: common genetic polymorphisms that alter activity. Mol Pharmacol 1998;53:708-17.

16. Yan L, Galinsky RE, Bernstein JA, Liggett SB, Weinshilboum RM. Histamine N-methyltransferase pharmacogenetics: association of a common functional polymorphism with asthma. Pharmacogenetics 2000;10:261-6.

17. Deindl P, Peri-Jerkan S, Deichmann K, Niggemann B, Lau S, Sommerfeld C, Sengler C, Müller S, Wahn U, Nickel R, Heinzmann A. No association of histamine- N-methyltransferase polymorphism with asthma or bronchial hyperresponsiveness in two German pediatric populations. Pediatr Allergy Immunol 2005;16:40-2.

18. Sharma S, Mann D, Singh TP, Ghosh B. Lack of association of histamine-N-methyltransferase (HNMT) polymorphisms with asthma in the Indian population. J Hum Genet 2005;50:611-7.

19. Darsow U, Pfab F, Valet M, Huss-Marp J, Behrendt H, Ring J, Ständer S. Pruritus and atopic dermatitis. Clin Rev Allergy Immunol 2011;41:237-44.

20. Petersen J, Drasche A, Raithel M, Schwelberger HG. Analysis of genetic polymorphisms of enzymes involved in histamine metabolism. Inflamm Res 2003;52 Suppl 1:S69-70.

21. Gould HJ, Sutton BJ, Beavil AJ, Beavil RL, McCloskey N, Coker HA, Fear D, Smurthwaite L. The biology of IGE and the basis of allergic disease. Annu Rev Immunol 2003;21:579-628.

22. Ständer S, Steinhoff M. Pathophysiology of pruritus in atopic dermatitis: an overview. Exp Dermatol 2002;11:12-24.

23. Kitawaki T, Kadowaki N, Sugimoto N, Kambe N, Hori T, Miyachi Y, Nakahata T, Uchiyama T. IgE-activated mast cells in combination with pro-inflammatory factors induce Th2-promoting dendritic cells. Int Immunol 2006;18:1789-99.

24. Reuter S, Stassen M, Taube C. Mast cells in allergic asthma and beyond. Yonsei Med J 2010;51:797-807. 